The Historical Journal, 64, 1 (2021), pp. 70-97 (C) Cambridge University Press 2020.

This is an Open Access article, distributed under the terms of the Creative Commons AttributionNonCommercial-NoDerivatives licence (http://creativecommons.org/licenses/by-nc-nd/4.o), which permits non-commercial re-use, distribution, and reproduction in any medium, provided that no alterations are made and the original article is properly cited. The written permission of Cambridge University Press must be obtained prior to any commercial use and/or adaptation of the article.

doi:10.1017/Soo $18246 X_{19000591}$

\title{
J. R. SEELEY AND JAPAN'S PACIFIC EXPANSION*
}

\author{
MARTIN DUSINBERRE \\ University of Zurich
}

\begin{abstract}
A B STRACT. In the late nineteenth century, as Japanese scholars, traders, and labourers began to cross the Pacific Ocean in ever greater numbers, Tokyo-based intellectuals started to think about the significance of the ocean for the upcoming century. One prominent articulation of this 'Pacific age' was the result of an intellectual dialogue between a young Japanese student, Inagaki Manjirō (I86I-I908), and his Cambridge professor, John Robert Seeley (I834-95). Traditionally framed as a relationship of 'influence' from teacher to pupil, and thus from West to East, the emergence of the 'Pacific age' was in fact the result of a sophisticated modulation of ideas from Seeley's The expansion of England (I883) into the rapidly changing politics of early I89os Japan. This article traces that modulation in Inagaki's published works between I89o, when he graduated from Cambridge, and I895, when Japan defeated China in the First Sino-Japanese War. It argues that Seeley's analyses, in Inagaki's hands, gave a significant impetus to existing expansionist visions in Japan, and thus constitute one example of late nineteenth-century history being written in the discursive space between Europe and East Asia.
\end{abstract}

If history-writing is an act of translation, of rendering a foreign country intelligible to the reader or seminar student, then simply for the thrills and spills I

Historisches Seminar, Universität Zürich, Karl Schmid-Strasse 4, 8006 Zürich, Switzerland martin. dusinberre@hist.uzh.ch

*I would particularly like to thank Gonzalo San Emeterio Cabañes, Lina Zbinden, and Tamara Ann Tinner for research assistance during the writing of this article in 2017 and 2018. Joan Judge, Leigh Jenco, Birgit Tremml-Werner, Helena Jaskov, David Möller, Bill Tsutsui, Nadin Hée, and two anonymous reviewers of the Historical Journal kindly commented on earlier drafts, as did other colleagues and invitees of the HERA project 'East Asian uses of the European past' (2016-19). That project was funded by the European Union's Horizon 2020 research and innovation programme under grant agreement no. 649307, and I extend thanks also to the Swiss National Science Foundation. I am grateful to the BA students of my autumn 2018 colloquium at the University of Zurich for allowing me to refine these ideas in teaching. 
would seek out a land far removed from my daily pastures - distant from my childhood memories of Cambridge, England, from my working life in Switzerland, and from a community of scholars also interested in Japanese historiography. Ideally, I would be able to write about Japan's late nineteenthcentury expansion through the biography of a man such as Sanuki Jūkichi. Born in $185^{8}$ into a farming household, Sanuki grew up in a small town to the south-west of Hiroshima, close to the Inland Sea coast. In May 1885 , he was declared of sound mind and body by an older relative; a few weeks later, he boarded the Yamashiro-maru and crossed the Pacific Ocean to begin a new life as a sugar plantation labourer in the Kingdom of Hawai' ${ }^{1} .^{1}$ For the next five years, Sanuki worked at the Hakalau plantation on Hawai'i Island itself. On 24 April 189o, he then boarded a barque called the Enoch Talbot, bound for Adelaide, where he landed two months later; but in Australia he disappears from the historical record. ${ }^{2}$

Despite these all too brief details, Sanuki's life would be worthy of translation because his migrations from Japan to the Kingdom of Hawai' $i$, and then on to the Australian colonies, embodied what contemporary Japanese scholars came to call the 'Pacific age'. As we shall see, this term was the outcome of intellectual fermentations that occurred roughly between 1885 and $1890-$ that is, in the same years as Sanuki's transpacific crossings. In an ideal world, therefore, Sanuki would be studied as a co-producer of the 'Pacific age' discourse, in that his migrations, and those of thousands of other Japanese men and women like him, gave material reality to otherwise abstract ideas about Japan's past and future place in world history. Thus, we would write a history which drew as equally on the experiences of the labourers as on those of the literati - while also not ignoring the animal actors, whose own migrations were so central to what scholars call the 'co-crafting' of the Pacific world. ${ }^{3}$ But the archival world is not ideal: Sanuki's voice does not speak as loudly as those of the scholars, essayists, lecturers, and journalists whose written records comprise my sources in the following pages; as a consequence, the protagonists of this piece are far closer to the habitus of home and work than I would like.

${ }^{1}$ Hiroshima Prefecture 広島県編, ed., Hiroshima-ken ijūshi: shiryōhen 広島県移住史 : 資料編 (The migration history of Hiroshima prefecture: primary sources) (Tokyo, 1991), pp. 8-9. See also Martin Dusinberre, 'Writing the on-board: Meiji Japan in transit and transition', Journal of Global History, 11 (2016), pp. 271-94.

${ }^{2}$ My brief biography of Sanuki Jūkichi 讃岐十吉 (alternatively 重吉) comes from the Diplomatic Archives of the Ministry of Foreign Affairs (DAMFA), Japan, 'Dekaseginin meibo no bu' 出稼人名簿之部 ('Names of out-migration labourers') folder, 3.8.2.5-14, and 'Hawai imin’ 布哇移民 (Hawai‘i emigration) folder, unnumbered, vol. I; The Daily Bulletin (Honolulu), 24 April 1890 (accessed through https://chroniclingamerica.loc.gov); and The Advertiser (Adelaide), 3o June 1890 (accessed through https://trove.nla.gov.au).

3 On the 'co-crafting' or 'co-construction' of the Pacific world between humans and animals, see, respectively, Ryan Tucker Jones, 'Running into whales: the history of the north Pacific from below the waves', American Historical Review, 118 (2013), pp. 349-77; and Gregory Rosenthal, Beyond Hawai' $i$ : native labor in the Pacific world (Berkeley, CA, 2018), p. 54. 
That said, the reason why historians should care about articulations of the 'Pacific age' as rhetorical framings for the world in which Sanuki moved is that they constituted something new in the global outlook of many Japanese people in the late nineteenth century. Sanuki's crossing to Hawai'i, as part of a second shipment of Japanese labourers (the first had left in January 1885), was the first time in more than $25^{\circ}$ years that the central state had permitted the mass migration of Japanese subjects overseas. Meanwhile, the intellectual struggle to formulate a coherent set of ideas about Japan's relationship to the Pacific Ocean grew out of the fact that, until the mid-nineteenth century, the world's largest maritime space had only minimally figured in Japanese thinking. As Marcia Yonemoto has shown, to Edo period (1600-1868) scholars the Pacific was a site of fear and ambivalence, its status encapsulated in Nagakubo Sekisui's 長久保赤水 (1717-1801) 'Annotated map of the mountains and seas of all the world's countries' (c. 1790). This map split the Pacific into two bodies of water, the 'Small Eastern Sea' (close to Japan) and the 'Large Eastern Sea' (far away towards North America), and thereby 'cut the vast Pacific down to size'. Maps, according to Yonemoto, were 'the coded and contextual language used to craft the notion of the Small Eastern Sea as a regional ocean basin, reinforcing Japan's sense of attachment to northeast Asia while dividing it from the "new" world, about which the Japanese knew little'.4

A century later, however, this conceptual divide between Japan and the larger Pacific Ocean was no longer tenable in economic, military, or intellectual terms - just as the Sinocentric worldview on which it had been based was similarly coming under attack, most famously in Fukuzawa Yukichi's 福澤諭吉 $\left(1835^{-1901)}\right.$ call for Japan to 'cast off Asia' (March 1885).5 Whether it be in waves of labour migration, in networks of Japanese doctors, in naval explorations and the promotion of 'southern expansion' (nanshin 南進), in the search for resources such as guano and albatross feathers, or in the new infrastructures of marine science and fishing, growing numbers of Japanese people were active in the Pacific world by the beginning of the $1890{ }^{6}{ }^{6}$ As a

\footnotetext{
4 Marcia Yonemoto, 'Maps and metaphors of Japan's "small eastern sea” in Tokugawa Japan, 1603-1868', Geographical Review, 89 (1999), pp. 169-87, at p. 177. For an image of the map, see: https://www.wdl.org/en/item/14749/view/1/1/. As Jonas Ruegg has recently argued, the Tokugawa shogunate remained interested in exploring the near Pacific until the late seventeenth century, inspired in part by the mythical Isles of Gold and Silver - both of which still appear in Nagakubo's map: Jonas Ruegg, 'Mapping the forgotten colony: the Ogasawara islands and the Tokugawa pivot to the Pacific', Cross-Currents, 23 (June 2017), pp. 109-57, at p. 117 .

5 For a reconsideration of the significance of Fukuzawa's essay, see Pekka Korhonen, 'Leaving Asia? The meaning of Datsu-A and Japan's modern history', Asia-Pacific Journal: Japan Focus, 11 (2013), pp. 1-19.

6 Takashi Nishiyama, 'Doctors for frontier expansion: Japanese physicians in Hawaii, 1868 1924', East Asian Science, Technology and Society: An International Journal, 12 (2018), pp. 257-75; Charles Schencking, 'The imperial Japanese navy and the constructed consciousness of a South Seas destiny, 1872-1921', Modern Asian Studies, 33 (1999), pp. 769-96; Hiraoka Akitoshi 平岡昭利, Ahōdori to 'teikoku' Nihon no kakudai: Nan'yō no shimajima e no shinshutsu kara shinryaku e
} 
consequence, the Pacific - and not just the generic 'Southern Seas' (Nan'ȳo 南 洋) - became an object of discursive interest for intellectuals who were already beginning to think about the nature of Japanese expansionism. But the challenge remained: how were they to conceptualize a space that had hitherto not been central to narratives of Japanese history?

In this article, I argue that time was central to the ways in which some Japanese scholars began to understand the Pacific world in the late nineteenth century. My focus is not on time in its material vestiges - a topic that has led to important new research on how (to take one example) Japanese people in the Edo period made the clock a part of their daily lives. ${ }^{7}$ Rather, my starting point is the assumption that, for Japanese intellectuals to articulate a coherent idea of 'the Pacific', they needed first to create a historical frame of understanding. This was a challenge similar - and running parallel - to the much more substantial project of reorienting Japan in East Asian history (more substantial by dint of Japan's long cultural and intellectual interactions with the Sinosphere) ${ }^{8}$ More generally, the articulation of the Pacific as a site of Japanese history spoke to what Christopher Hill identifies as the two key questions with which anyone writing national history at the end of the nineteenth century had to grapple: 'First, what is the place of national territory in global economic and political space? Second, what is the relationship of the present national form of territoriality to those forms that have been superseded?'9 As I shall argue, to think of Japan's territorial relationship to the Pacific spatially, certain intellectuals found it useful to think temporally; and in conceptualizing forms that had been superseded (that is, the past), those intellectuals wrote not only of the present but also of future histories.

Although the final articulation of these writings centred on a national territory - in this case, on Japan - their constructions were profoundly global in nature. By way of brief comparison, the history of Hokkaido demonstrates how global time, space, and disparate intellectual traditions became entangled

\footnotetext{
アホウドリと「帝国」日本の拡大 : 南洋の島々への進出から侵略へ (Albatrosses and the expansion of 'imperial' Japan: from advance to invasion of the Southern Seas islands) (Tokyo, 2014); Paul Kreitman, 'Feathers, fertilizers and states of nature: use of albatrosses in the U.S.-Japan borderlands' (Ph.D. thesis, Princeton, NJ, 2015); Nadin Hée, 'Negotiating migratory tuna: territorialization of the oceans, trans-war knowledge and fisheries diplomacy', Diplomatic History, 44 (forthcoming).

7 Yulia Frumer, Making time: astronomical time measurement in Tokugawa Japan (Chicago, IL, 2018); Sebastian Conrad, "Nothing is the way it should be": global transformations of the time regime in the nineteenth century', Modern Intellectual History, 15 (2017), pp. 821-48. For a pioneering early account of 'factory time' in modern Japan, see Thomas C. Smith, 'Peasant time and factory time in Japan', Past EO Present, 111 (1986), pp. 165-97.

${ }^{8}$ On Japan's recalibration of its historical relationship to China, see Stefan Tanaka, Japan's Orient: rendering pasts into history (Berkeley, CA, 1993). On Japan's place within the Sinosphere more generally, see Joshua Fogel, Articulating the Sinosphere: Sino-Japanese relations in space and time (Cambridge, MA, 2009).

9 Christopher L. Hill, National history and the world of nations: capital, state, and the rhetoric of history in Japan, France, and the United States (Durham, NC, 2008), p. 9.
} 
in early Meiji Japan (1868-1912) - and, in truth, always had been, even during the so-called 'closed country' centuries (see David Mervart's contribution to this special issue). Until 1869, what is today Japan's northernmost main island, along with other islands in its northern vicinity, were collectively known as Ezo 蝦夷 (literally 'land of barbarians'). Even before the Meiji Restoration, prominent intellectuals had called for Ezo to be settled by 'mainlanders' at the expense of the indigenous Ainu peoples. After 1869, such calls were buttressed by a selective reading of Thomas Robert Malthus (1766-1834), whose ideas were first debated in Japanese in $1876-7$. Japanese overpopulation at home, it was argued, justified expansion in Hokkaido and beyond. ${ }^{10}$ The vanguard of this colonization effort was a body of government-subsidized farmersoldiers, known as the tondenhei 屯田兵. But this terminology of the tonden was actually Chinese in origin (tuntian), having been most recently employed by the Qing dynasty during its eighteenth-century expansion into Xinjiang. ${ }^{11}$ Meanwhile, in order to help the farmer-soldiers cultivate land in Hokkaido on a far greater scale than was possible on mainland farms, the Meiji government employed agriculturalists from the United States, some of whose expertise was derived from the settlement of the American west. ${ }^{12}$ As for the new name, 'Hokkaidō' 北海道 (literally 'northern sea circuit') extended the 'five provinces, seven circuits' logic of Japan's seventh- to eighth-century ritsuryō 律令 state, itself modelled on the Tang dynasty. ${ }^{13}$ In other words, the Meiji state's expansion into Hokkaido was a confluence of ideas, concepts, and expertise which drew on Qing, European, and North American pasts, as well as on particular elements of Japan's own history.

And so it was with the articulation of Japan's 'Pacific age'. At one level, the significance of this phrase can only be grasped by placing it in the wider context of what Akira Iriye once called 'an indigenous tradition of expansionism in Japan' - especially with reference to early modern Japan's maritime engagements with East and South-east Asia (see Birgit Tremml-Werner's contribution to this special issue). ${ }^{14}$ At a second level, we can think of the 'Japanese Pacific' as emerging from the ways in which late nineteenth-century intellectuals imagined Japan's relationship to the emerging empire's 'frontier' in

10 Sidney Xu Lu, 'Colonizing Hokkaido and the origin of Japanese trans-Pacific expansion, 1869-1894', Japanese Studies, 36 (2016), pp. 251-74.

${ }^{1}$ Peter C. Purdue, China marches West: the Qing conquest of central Eurasia (Cambridge, MA, 2005), pp. 324-57. See also Michele M. Mason, Dominant narratives of colonial Hokkaido and imperial Japan: envisioning the periphery and the modern nation-state (New York, NY, 2012), pp. $3^{1-55}$.

${ }_{12}$ Fumiko Fujita, American pioneers and the Japanese frontier: American experts in nineteenth-century Japan (Westport, CT, and London, 1994), esp. pp. $15^{-4} 4^{1}$.

13 Goki-shichidō五畿七道 (five provinces, seven circuits) was a key organizing principle of the ritsuryō state. For its spatial appropriation in the 1870 , see Mark Ravina, To stand with the nations of the world: Japan's Meiji restoration in world history (New York, NY, 2017), p. 174.

${ }^{4}$ Akira Iriye, Pacific estrangement: Japanese and American expansion, I897-I9I I (Cambridge, MA, 1972), p. 18 . 
general and to North America in particular. ${ }^{15}$ But, thirdly, there was also a crucial European context to Japanese articulations of the 'Pacific', as Pekka Korhonen noted in a ground-breaking article published in 1996. Cited by the aforementioned Marcia Yonemoto, and by many other scholars, ${ }^{16}$ Korhonen's essay began with a striking claim:

The first person ever to use the term Pacific Age was the Japanese political economist Inagaki Manjirō. Inagaki studied the history of Great Britain's expansionary policies under the guidance of the British historian John Robert Seeley at Cambridge University during the late 188 os. Seeley had been influenced by the German geographer Carl Ritter. Through Inagaki a certain style of European nineteenth-century visionary rhetoric was introduced into discussions about the Pacific future. That is an interesting point in itself, but even more interesting are the shifts in perspective that resulted from this transference of concepts into a different context. ${ }^{17}$

Itself building on the work of Watanabe Akio, Korhonen's essay went on to sketch a late nineteenth-century Japanese understanding of the Pacific Ocean, thus contributing to an English-language historiography which had already begun to challenge the problematic idea of the Pacific as a Spanish, English, or American 'lake' - that is, of the Pacific as merely a Euro-American construct. ${ }^{8}$ Korhonen's identification of the little-known Inagaki Manjirō 稲垣満次郎 (1861-1908), and his noting of Carl Ritter's (1779-1859) influence on Inagaki as refracted through J. R. Seeley (1834-95), suggested a complex intellectual genealogy. In the opening pages of his article, Korhonen traced this genealogy in Inagaki's 1890 book, Japan and the Pacific, before jumping forward to a Japanese-language publication from 1892, in which Inagaki first used the phrase Taiheiyo jidai 太平洋時代 ('the Pacific age'). 'Inagaki was the one who named the new age', Korhonen argued. ${ }^{19}$ But, he continued, Inagaki's expansionist vision must also be compared to those of contemporary American thinkers, including Alfred Thayer Mahan (1840-1914) and Theodore Roosevelt (1858-1919).

15 See Eiichiro Azuma, In search of our frontier: Japanese America and settler colonialism in the construction of Japan's borderless empire (Berkeley, CA, 2019). I am very grateful to Professor Azuma for sharing prepublication drafts of this manuscript with me.

${ }^{16}$ Yonemoto, 'Maps and metaphors', p. 171; David Armitage and Alison Bashford, 'Introduction: the Pacific and its histories', in David Armitage and Alison Bashford, eds., Pacific histories: ocean, land, people (Basingstoke, 2014), pp. 1-28, at p. 19.

${ }_{17}$ Pekka Korhonen, 'The Pacific age in world history', Journal of World History, 7 (1996), pp. $4^{1-70}$, at p. 41, emphasis in original.

${ }_{18}$ See, for example, Arif Dirlik, 'The Asia-Pacific idea: reality and representation in the invention of a regional structure', Journal of World History, 3 (1992), pp. 55-79, at pp. 69-73. Korhonen notes that his essay was 'inspired by' Dirlik's work; and he prominently acknowledges Watanabe Akio 渡辺昭夫, Ajia Taiheiyō no kokusai kankei to Nihon アジア・太平洋の国 際関係と日本 (Japan and the international relations of the Asia-Pacific region) (Tokyo, 1992), pp. 98-102.

${ }^{19}$ Korhonen, 'The Pacific age', p. 45. 
In what follows, I leave questions of intellectual firsts and of North American contexts for another day. Rather, in focusing on a watery expanse whose spatial conceptualization in global intellectual histories remains understudied in comparison to its Atlantic, Indian, or Mediterranean counterparts, ${ }^{20}$ my challenge to Korhonen's analysis of the 'Pacific age' - my debt to his work notwithstanding-arises from his model of the introduction and transference of ideas from Europe to East Asia. Recent research in the history of knowledge has pointed out that 'transfer' is a deeply problematic metaphor for intellectual history: it implies the movement of an object from A to B without any modulation along the way, and thus reinforces a model of unilinear knowledge diffusion, usually from Europe to the non-European world. ${ }^{21}$ As Kapil Raj and others have argued, to overcome such assumptions about the diffusion, dissemination, or transmission of ideas, scholars would do better to think in terms of "processes of encounter, power and resistance, negotiation, and reconfiguration' - that is, to focus on the construction of what Harald Fischer-Tiné pithily calls pidginknowledge. ${ }^{22}$ In the case of Inagaki's coining of the 'Pacific age', this means, first, that we must examine more closely the nature of Inagaki's engagement with Seeley's ideas, thereby questioning simplistic notions of the Cambridge professor's 'influence' or 'impact' on his young Japanese student..23 This will be the task for the first half of my article.

To consider processes of intellectual negotiation and reconfiguration also demands that we have a better understanding of what happened between the publication of Inagaki's English-language monograph in 1890 and his Japanese-language articulation of the 'Pacific age' in 1892: this constitutes my article's second half. For, in fact, the 'transference' that culminated in Inagaki's articulation of the Pacific age was a good deal less smooth than Korhonen implies. The phrase came out of Inagaki's struggles to translate - linguistically and conceptually - his understanding of Seeley's work for a Japanese readership. It therefore follows that the 'Pacific age' was not the endpoint of Inagaki's thinking but merely a port of call. The bigger journey was towards an understanding of Japan's place in a world of current and future Great Power rivalries - and thus towards a positioning of Japan in historical time. The 'Pacific age' was an articulation of this future moment, but it was only one formulation of a bigger temporal narrative which was emerging in Japan

\footnotetext{
${ }^{20}$ See, for example, the absence of the Pacific Ocean in a recent special issue of Global Intellectual History (2018) entitled 'Conceptions of space in intellectual history'.

${ }^{21}$ The classic articulation of the 'transmission' and 'diffusion' thesis is George Basalla, 'The spread of Western science', Science, $15^{6}$ (1967), pp. 611-22. As will be clear, my own approach in what follows grows out of James A. Secord, 'Knowledge in transit', Isis, 95 (2004), pp. $654-72$.

${ }^{22}$ Kapil Raj, 'Beyond postcolonialism ... and postpositivism: circulation and the global history of science', Isis, 104 (2013), pp. 337-47, at p. 343; Harald Fischer-Tiné, PidginKnowledge: Wissen und Kolonialismus (Zürich, 2013), pp. 12-13.

${ }^{23}$ For a critique of 'influence' and 'impact' as analytical terms for intellectual historians, see David Mervart, 'Is one book world not enough? The Eurasian republic of letters before the nineteenth century', Global Intellectual History, 3 (2018), pp. 1-16, at pp. $7-8$.
} 
by the early 1890 s, namely expansion. It was in the discursive space between the histories of Seeley and the work of prominent writers such as Tokutomi Sohō 徳富蘇峰 $\left(1863^{-1957)}\right.$ that Inagaki wrote about the significance of the Pacific Ocean to the Japanese nation. Indeed, as I shall show, the lesserknown figure of Inagaki was very likely the key mediator between Seeley's 1883 The expansion of England and Tokutomi's 1894 On the expansion of greater Japan-a mediation that Tokutomi scholars have hitherto overlooked.

In other words, as Joan Judge has observed for the ways in which European pasts were discussed in early twentieth-century China, non-Japanese ideas such as those of Seeley 'did not supplant an existing conceptual universe'. Instead, in thinking about how history was made between Europe and East Asia, scholars could start by acknowledging how ideas were translated into 'the historical lexicon of that universe'. As Judge argues, it is therefore essential for us to understand this 'host' language - in our case, the language of Japanese expansionism in the late nineteenth century - so as to decode how foreign ideas were appropriated and assimilated. Thus, 'a grasp of the concrete microprocesses through which Western ideas were mediated is essential to our understanding of the more abstract macro-processes of ideational translation'. ${ }^{24}$ To reconstruct these micro-processes, I draw on a methodology of 'sites of citation'-thinking not only about where and when Inagaki articulated his ideas but also how, in his engagement with Seeley, he projected The expansion of England onto the discursive site of the Pacific Ocean. ${ }^{25}$ In these ways, I hope both to build on Korhonen's work in disentangling an understudied element of late nineteenth-century Japanese oceanic rhetoric, and also to demonstrate the longer life of The expansion of England beyond the Anglo-American world in which it is usually studied. Thus, this is not a case study of wholesale transference from Europe to East Asia, but rather of histories constructed in migrations between the two.

Like all good stories, this one begins in Switzerland. Circa 1881, two Cambridge dons were holidaying in the mountains. At some point, one, John Robert Seeley (of Gonville and Caius College), announced to the other, Oscar Browning (of King's College, 1837-1923), that he had been visited with the idea for a new book. Browning recalled, 'I remember [Seeley] coming to me one morning full of the scheme which had been revealed to him the evening before, treating it as if it were something outside himself, and as if he dreaded the responsibility

${ }^{24}$ Joan Judge, The precious raft of history: the past, the West, and the woman question in China (Stanford, CA, 2008), p. 5 .

25 Kris Manjapra, 'Transnational approaches to global history: a view from the study of German-Indian entanglement', German History, 32 (2014), pp. 274-93, at p. 288, in turn inspired by the methodology of Ronit Ricci, Islam translated: literature, conversion, and the Arabic cosmopolis of South and Southeast Asia (Chicago, IL, 201 1). 
which had been laid upon him to work it out. ${ }^{26}$ We can only speculate on whether it was the heady air of Swiss federalism that provided the crucial intellectual spark to Seeley, himself a renowned imperial federalist; ${ }^{27}$ at any rate, the dreaded scheme was to bring him worldwide renown.

Delivered as a series of undergraduate lectures in the autumn of 1881 and spring of 1882 , and published largely without revision in $188_{3}$, The expansion of England laid out Seeley's philosophy of history through a consideration of the English past since approximately the sixteenth century. History, he argued, should 'pursue a practical object'; an overview of English history 'should state some conclusion to which it leads'. He claimed that 'since the future grows out of the past, the history of the past of England ought to give rise to a prophecy concerning her future'.${ }^{28}$ But the historical progress of the English state was not simply towards liberty and democracy. Instead, it was characterized by a trend more conspicuous, if hitherto understudied: 'I mean the simple obvious fact of the extension of the English name into other countries of the globe, the foundation of Greater Britain.' And then, in one of his most oft-cited observations, he added: 'There is something very characteristic in the indifference which we show towards this mighty phenomenon of the diffusion of our race and the expansion of our state. We seem, as it were, to have conquered and peopled half the world in a fit of absence of mind.' 29

Thus, the title of Seeley's first lecture (and chapter), 'Tendency in English history', referred to 'the tendency to expansion which England has so long displayed'. $3^{\circ}$ This was a tendency that Seeley identified by rethinking popular narratives of English history in the eighteenth century across the temporal divisions of monarchical reigns. Instead, he urged his listeners/readers to think of what he called England's 'foreign wars' (he calculated that there were seven between 1688 and 1815 ) as part of a single historical phenomenon. To the extent that he was thus bundling previously disparate histories into a single concept, namely expansion, Seeley was engaged in the practice of colligation. 'Colligation' literally means 'to tie, group, or join together'. Within the practice of history, it refers to the act of 'integrat[ing] units of information to form something new and to thus create novel historiographical information, which cannot be thought to have existed before this act of creation'; in other words, it denotes the act of historiographical synthesis. ${ }^{31}$ Seeley did not articulate his approach

\footnotetext{
${ }^{26}$ Oscar Browning, 'Some personal recollections of Sir John Seeley and Lord Acton', Albany Review, 2 (Oct. 1907-March 1908), cited in John Gross, 'Editor's introduction', in John Robert Seeley, The expansion of England (Chicago, IL, 1971; orig. edn 1883), p. xvii.

${ }^{27}$ On British imperial federalism, see Duncan Bell, The idea of greater Britain: empire and the future of world order, I860-190o (Princeton, NJ, 2007).

${ }^{28}$ Seeley, Expansion of England, pp. 7-8.

${ }^{29}$ Ibid., p. 12.

$3^{\circ}$ Ibid., p. 18, emphasis added.

$3^{1}$ Jouni-Matti Kuukkanen, Postnarrativist philosophy of historiography (New York, NY, 2015), pp. 98-9. As Kuukkanen points out, William Walsh was the first scholar to think of colligation as a historiographical practice, in his $194^{2}$ essay, 'The intelligibility of history'. Key examples of
} 
using this language; but he did talk of the 'rearrangement' of historical events and of 'a new principle of grouping'. This enabled him to break down his bigger story-expansion-into new temporal phases, during which the history of England, far from being centred on parliamentary debates in Westminster, expanded into greater Britain and thus incorporated colonies as different as Canada or India. $3^{2}$

Although Seeley did not intend it, his act of historiographical rearrangement, and his insistence on the relationship between the past and the future - 'on the question whether Greater Britain, now that it exists, may be expected to prosper and endure or to fall' 33 - would later facilitate the modulation of his ideas into a Japanese context, even before The expansion of England was itself translated. But notwithstanding the potential for Seeley's historiographical strategies to travel, we should first simply note that his book touched a nerve within late Victorian Britain and beyond. Admirers of The expansion of England included such luminaries as the then prime minister William Gladstone (who had been influential in securing for Seeley the Regius professorship of history at Cambridge in 1869), Joseph Chamberlain, Cecil Rhodes, and Lord Tennyson. The book sold some 80 , ooo copies in the first two years after its publication, 34 and we may safely assume that one of those copies belonged to a young Japanese student who arrived to study in Cambridge in 1885 .

Inagaki Manjirō was the second son of a samurai retainer in the western domain of Hirado, not far from Nagasaki. In its sixteenth- and early seventeenth-century heyday, Hirado had been one of the most important trade entrepôts in East Asia - a hub for Chinese, Dutch, and (for ten years) English traders. 35 Though the domain fell into serious economic difficulties after the promulgation of the Tokugawa shogunate's so-called 'closed country' edicts, never to regain its former glory, it had nevertheless become a key centre of Dutch learning and translation by the early nineteenth century. Indeed, Hirado's bibliophile daimyo (lord) Matsura Kiyoshi 松浦清 (1760-1841) came to amass one of the largest collections of Western texts in the Tokugawa realm. $3^{6}$ The extent to which this intellectual hinterland played a role in the development of Inagaki's subsequent thought remains a topic for future research. Later scholars would label him one of the 'Hirado triumvirate', a group that included the writers Suganuma Teifū 菅沼貞風 $\left(1865^{-89}\right)$ and

colligatory concepts, for Walsh, were the industrial revolution and the Enlightenment; one of the colligatory concepts that Kuukkanen himself discusses is 'Christian expansion' (pp. 104-5).

$3^{2}$ Seeley, Expansion of England, pp. 96-1 12, 201-1 5. For 'rearrangement' and 'a new principle of grouping', see p. $9^{8}$.

33 Ibid., p. 107.

34 Gross, 'Editor's introduction', pp. xi-xii.

35 Adam Clulow, 'From global entrepôt to early modern domain: Hirado, 16o9-1641', Monumenta Nipponica, 65 (2010), pp. 1-35.

${ }^{36}$ David Mervart, 'The republic of letters comes to Nagasaki: record of a translator's struggle', Transcultural Studies, 6 (2015), pp. 8-37, at pp. 16-19. 
Ura Kei'ichi 浦敬一 (186o-89).37 Inagaki wrote less explicitly about his home domain than Suganuma, whose posthumous 1892 monograph on the commercial history of greater Japan included a 135-page appendix, A history of Hirado trade. $3^{8}$ But as we shall shortly see, Hirado may have coloured his reading of recent British imperial history; and, in the second half of the $188 \mathrm{os}$, the domain remained part of his daily life, owing to the fact that Inagaki was asked to accompany Matsura Atsushi 松浦厚 (1864-1934), son of the last Hirado daimyo and great-great-grandson of Matsura Kiyoshi, when Atsushi was sent to study at the University of Cambridge in August $1885 .{ }^{39}$

In today's age of international student exchanges, it is perhaps difficult for us to imagine the challenges faced by Inagaki, Matsura, and the other handful of Japanese students at Cambridge in the 1880 os to 'fit in' to university life. As Greg Dening has documented, the language and customs of the university could be quite alien even to a young man from nearby East Anglia - in this case, the future astronomer William Gooch (1770-92), who came to Cambridge in ${ }_{17} 78$ and encountered for the first time the Tripos and hoi polloi, the wranglers, the Senate House examinations, and sizars..$^{\circ}$ If this was a lexicon bewildering to the son of a Norfolk barber in the late 1780 s, then it must have been all the more so to the son of a Hirado retainer in the late $1880 \mathrm{os}$. ('Tripos', 'Senate House', and 'hoi polloi' bewildered even a don's son growing up in Cambridge in the late 1980 os-but enough about him.) Cambridge was in a period of transition during Inagaki's years, however: in 1887 , in response to the presence of not only Japanese but also Indian undergraduates, the university senate voted to allow students from Asia to take their examinations in English and not Greek. ${ }^{1}$ Indeed, Indians in late Victorian Britain, though small in number, constituted a significant element of the

37 Suganuma's given name, Teifū (貞風), can also be read Tadakaze. The phrase Hirado no sanketsu 平戸の三傑 ('the Hirado triumvirate') comes from Yoshikawa Toshiharu 吉川利治, ““Ajia shugi”'sha no Tai-koku shinshutsu: Meiji chūki no ikkyokumen’「アジア主義」者の タイ国進出：明治中期の一局面 (“The “Asianists” in Thailand: one aspect in the mid-Meiji era'), Tōnan Ajia kenkyū, 16 (1978), pp. 78-93. See also n. 76 below. Another Hirado 'son' who was active in South-east Asia was Ishibashi Usaburō 石橋禹三郎 (1869-98), who studied in Oakland between 1888 and 1891 and was an active promoter of Japanese emigration to Siam between 1893 and 1895: see Azuma, In search of our frontier, pp. 63-6.

$3^{8}$ In Tokyo in the early 188 os, both Inagaki and Suganuma studied under, among others, Nakamura Masanao 中村正直 $\left(183^{2-91)}\right.$, the bestselling translator of Samuel Smiles and John Stuart Mill. See also Yano Tōru 矢野暢, Nanshin no keifu 南進の系譜 (A genealogy of the southward advance) (Tokyo, 1975), pp. 195-200.

39 Matsura Atsushi was the eldest son of Hirado's twelfth and last daimyo, Matsura Akira 松浦 詮 $(1840-1908)$.

$4^{\circ}$ Greg Dening, The death of William Gooch: a history's anthropology (Honolulu, HI, 1995), pp. $7^{6-111 .}$

$4^{1}$ The Board of Oriental Studies had already proposed, in 1878 , that Indian students be allowed to take Sanskrit or Arabic instead of Latin or Greek in their examinations: Noburo Koyama, 'Inagaki Manjirō, 1861-1908: a diplomat who recognized the importance of the Asia-Pacific region to Japan', in Hugh Cortazzi, ed., Britain and Japan: biographical portraits, vi (Dover, 2007), pp. $44^{-} 5^{2}$, at p. 47 . 
popular English imagination of the world beyond Britain, $4^{2}$ and it was exactly this imagination of the 'greater Britain' - of the historical and contemporary significance of the colonies in particular - that lay behind Seeley's famous book.

Inagaki got to study under Seeley's tutorage in 1888 , when he entered Gonville and Caius College (which was also William Gooch's alma mater). Two years later, armed with his examination-tested English, he published his first monograph and completed his studies in Cambridge. Based on one of his two graduation theses, 43 Japan and the Pacific, and a Japanese view of the Eastern Question was dedicated to Seeley, and the book's second part ('The Eastern Question') drew especially on The expansion of England and Seeley's 'A short history of Napoleon the First' (1886).44 But, as Lord Knutsford wrote to Inagaki, 'the first part of the book is to me the most interesting. I prefer to consider the important part which Japan will play in the history of the future to looking back to the history of the past, the Crimean War, \& the action of Port Manning.' 45 As for Knutsford, so for us: it is in part one, Japan and the Pacific, that Inagaki's interpretation and application of Seeley's ideas is most original; equally, this part would be central to Inagaki's subsequent articulation of his Pacific-related ideas in Japanese.

Inagaki opens Japan and the Pacific with a Seeley-esque sentence of prophecy and periodization - a chronosophy, as it were: 'Without doubt the Pacific will in the coming century be the platform of commercial and political enterprise.' ${ }^{6}$ He continues: 'This truth, however, escapes the eyes of ninety-nine out of a hundred, just as did the importance of Eastern Europe in 1790, and of Central Asia in 1857.' 47 And with that, the reader is thrust into a historical overview of what Inagaki takes to be the great geopolitical rivalry of the nineteenth century, between England on the one hand and Russia on the other. (Seeley had similarly framed his analysis of the eighteenth century in terms of the great rivalry between England and France; he touched on the nineteenthcentury rivalry between England and Russia only briefly in his penultimate chapter.) Inagaki's argument is that, across the 1800 , the English-Russian rivalry had gradually moved eastwards, from Crimea to Persia and even to the Second Opium War (1856-6o), which Inagaki argues provoked Russia into

$4^{2}$ Antoinette Burton, At the heart of empire: Indians and the colonial encounter in late-Victorian Britain (Berkeley, CA, 1998).

43 The other was entitled 'A history of the migration of centres of commercial and industrial energies of the world': Junzo Iida, 'Japan's relations with independent Siam up to 1933: prelude to pan-Asian solidarity' (Ph.D. thesis, Bristol, 1991), p. 68.

44 Inagaki incorrectly referenced this as 'A short history of Napoleon the Great'.

45 Henry Holland, 1st Viscount Knutsford (secretary of state for the Colonies, 1887-92), to Inagaki, 15 June 1890 , reprinted in Inagaki Manjirō 稲垣満次郎, Tōhōsaku 東方策 (Eastern policy) (5th edn, Tokyo, 1894), front matter (unpaginated), emphasis added.

$4^{6}$ On chronosophy, see François Hartog, Regimes of historicity: presentism and experiences of time, trans. Saskia Brown (New York, NY, 2015), p. 11.

47 Manjiro Inagaki, Japan and the Pacific and the Japanese view of the Eastern Question (London, 189o), pp. $21-2$. 
agreeing (with China) its acquisition of Vladivostok in $185^{8}$ and (with Japan) of Sakhalin in 1859 . It was this growing Russian influence in the north Pacific, plus 'many other circumstances', which 'caused England to perceive the necessity of having a naval depot and commercial harbour on the Tong Hai [i.e. the East China Sea] and on the Yellow Sea'. $4^{8}$

At this point, having given his readers a whirlwind tour of the 'Great Game' in less than ten pages, Inagaki devotes the next seven pages to a relatively minor incident in European imperial history, namely the British occupation of Port Hamilton (Geomundo Island), off the southern coast of Korea, between 1885 and 1887.49 The importance of this occupation to Inagaki's worldview is suggested by the fact that, after his return to Japan in 1891 , one of his first published essays was devoted to what he called Britain's 'illegal' (fuhō 不法) actions in Port Hamilton. $5^{\circ}$ Exactly what triggered his interest in this particular episode is unclear. Perhaps it was the incident's timing, during Inagaki's first two years in Cambridge, such that he had to confront the disjuncture between abstract discussions of 'greater Britain' in university lecture halls and imperial realpolitik in his backyard. Perhaps it was the fact that Port Hamilton really was in Inagaki's backyard (Geomundo Island, less than two hundred kilometres from Hirado as the bird flies, was the closest Korean territory to Inagaki's home domain): here we see one possible influence of Hirado on Inagaki's writing. Perhaps it was an indirect way of questioning the diet of international-relations-as-gentlemanly-relations that Inagaki, as a founder member of the Japanese Club at Cambridge (established 1888), was fed in some of his extracurricular activities..$^{1}$

Whatever the reason, Port Hamilton was crucial to Inagaki's understanding of the Pacific Ocean more generally. In his 1891 Japanese essay, he insisted that one must understand the regional politics of this small Korean island in terms of its Pacific Ocean aspect (Taiheiyō no kyokumen yori mite 太平洋の局面

$4^{8}$ Ibid., p. 3o. British forces had captured the 'Chusan' (Zhoushan) islands, close to the ancient port of Ningbo, during the First Opium War $(1839-42)$, but it had been seen as a prized site for the British since at least the 1793 Macartney mission: see Henrietta Harrison, 'The Qianlong emperor's letter to George III and the early-twentieth-century origins of ideas about traditional China's foreign relations', American Historical Review, 122 (2017), pp. $680-701$.

49 For recent scholarship, see Sangpil Jin, 'The Port Hamilton (Geomundo) incident, 1885 1887: retracing another great game in Eurasia', International History Review, $4^{1}$ (2017), pp. 280303 .

$5^{\circ}$ Inagaki Manjirō 稲垣満次郎, 'Kyobuntō no senryō ni taishi Nihon wa kōhōjō kore wo koshōsuru koto wo eru ya ina ya’ 臣文島の占領に對し日本は公法上之を故障することを得 るや否や ('Regarding the possibility of Japan stopping the occupation of Port Hamilton through international law)', Tōhō kyōkai kaihō 東邦協會會報, 6 (Nov. 1891), pp. 31-40, reprinted in Tōhō kyōkai hōkoku 東邦協會報告, II (Tokyo, 1998), pp. 295-304.

$5^{1}$ Records from five of the Japanese Club's meetings (hereafter JCG) survive in the Cambridge University Library, Rare Books Room, Cam.d.21.32.4-. The lecture in December 1890 , the last meeting that Inagaki attended before leaving Cambridge, was delivered by the Rev. Dr C. E. Searle (Pembroke) on 'The comity of nations'. 
より見て); and the notion of examining 'general tendencies in the Pacific' (Taiheiyō no taiseijō 太平洋の大勢上) is one of the essay's key refrains..$^{2}$ In his 1890 English monograph, Inagaki's lengthy discussion of Port Hamilton, in which he methodically counters British government justifications for the occupation, serves to preface his central argument that 'Without doubt Japan is the Key of the Pacific'. 53

Although this Port Hamilton discussion may be easy to overlook, the prism that the incident offered Inagaki to understanding Japan's relationship to the Pacific was particularly original. In his focus on 'the Pacific', he was insisting on the ocean as a site of history-a place whose 'aspect' must be considered in world affairs - rather than as an empty vast space to be crossed in any journey between Asia and North America. And if Japan was 'the key' to this site, then it followed that any historical discussion of the Pacific must involve Japan, and vice versa. In this sense, Port Hamilton was a moment in the very recent British past that served to highlight the centrality of Japan to any world history narrative which would encompass Asia, British-Russian rivalry, and the Pacific Ocean 'in the coming century'. We are not yet at the articulation of an age, but already Inagaki's understanding of the Pacific is taking shape.

A few pages later, Inagaki cites Seeley for the first time - in the context not of political power but of commerce. In a short exposition on the geography and history of Japan (referencing the defeat of the Mongol invaders in 1281, the conquest of Korea by Hideyoshi Toyotomi in the $1590 \mathrm{os}$, and the subjugation of Taiwanese indigenous peoples in 1873), Inagaki writes: 'Look at a map of the world - the country lies between two of the largest commercial nations, viz., the United States and China ...'.54 Here, he footnotes a sentence from The expansion of England in which Seeley had observed the 'two gigantic neighbours' of the 'English world-empire', namely the United States and Russia. At first sight, Seeley's observation was seemingly a comment on the spatial organization of the world. In fact, however, it came in a chapter in which he proffered three different phases in the history of greater Britain: the first from the end of Elizabeth I's reign to the eighteenth century, the second the eighteenth century itself, and the third, that of England as a world empire with two gigantic neighbours. 55 As I have already noted, the division of time was central to Seeley's

\footnotetext{
$5^{2}$ Inagaki, 'Kyobuntō no senryō', p. 3o1; the phrase 'general tendencies' appears throughout, e.g. pp. 303, 304 .

53 Inagaki, Japan and the Pacific, p. 34, emphasis in original. Among his arguments, Inagaki refuted the idea that Port Hamilton would serve as a strategic bridge between the British colony of Hong Kong and the recently completed Canadian Pacific Railway: given Japan's geographical position between Korea and Canada, this would only work if there were an Anglo-Japanese alliance (p. 33).

54 Ibid., pp. $4^{6-7}$.

55 Seeley, Expansion of England, pp. 226-7.
} 
'rearrangement' of historical narratives, whether in 'phases', 'tracts of time', 'periods', 'epochs', 'moments', or 'stages'. $5^{6}$

That Inagaki understands Seeley's 'gigantic neighbours' comment to be a temporal observation is suggested by the fact that he quickly moves to a second citation from The expansion of England. Here, Seeley had drawn on the work of the German geographer Carl Ritter to posit three stages of civilization: 'the potemic which clings to rivers, the thalassic, which grows up around inland seas, and lastly the oceanic'.57 The impact of the New World, according to Seeley, was that it had spurred Europe to pass from the thalassic to the oceanic stage of history, a 'transformation' that for England had begun with the Elizabethan age and taken true form in the eighteenth century. $5^{8}$ Inagaki cites Seeley, in turn citing Ritter, and then suggests that, owing to Watt and Stephenson, the railway constitutes another stage of general civilization, such that 'it seems also to me that we might call the present era "the railwayoceanic".59 From railways, Inagaki moves to commerce, to the Japanese as 'born sailors', to the need for Japan to hold a closer relationship with Australia, and then to a final overview of the English position in the Pacific, and the likelihood of Japan at some point finding itself as lying between future combatants.

Inagaki's proposal of a new civilizational stage demonstrates the extent to which Seeley coloured his geopolitical imagination of Japan's place in the world, and thus in world history. The idea of historical stages was of course not exclusive to Seeley and Ritter: Inagaki would have known Fukuzawa Yukichi's An outline of a theory of civilization (itself drawing on Henry Thomas Buckle and François Guizot), which similarly posited three stages of world civilization. ${ }^{60}$ But Seeley was present in the binary framework of great power rivalry, which was a prelude to Inagaki's explaining Japan's key presence in the Pacific. Seeley was also present in Inagaki's own interest in stages and phases of historyand, concomitantly, in the idea that the past should explain something of the future. Inagaki did not use the term 'expansion' in his book, but The expansion of England's arguments pervade his work. They explain his interest in historical moments, such as the British occupation of Port Hamilton; and they are there in the other ways he discusses temporality, be it in terms of chronology ('the coming century') or phases of history.

In Japan and the Pacific, however, Inagaki's interest in the past had yet to coalesce into a single colligation. His articulation of a future age would, in fact, emerge from the problem of translation - from the question of how to

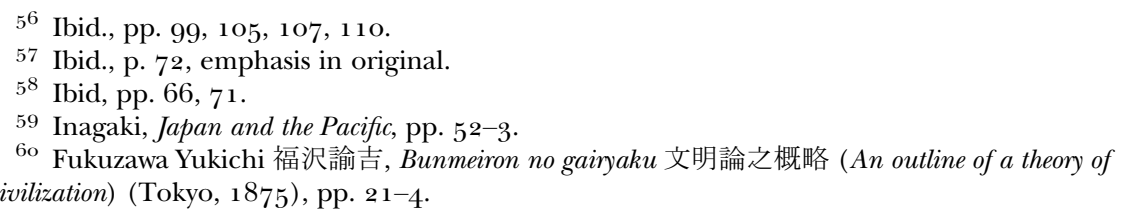


make his ideas (which for five years he had been formulating in English) speak to an audience of his Japanese peers.

\section{I I}

In November 1895 , Inagaki Manjirō rose to deliver a lecture for the Tōhō Kyōkai 東邦協会 (Oriental Society), in Tokyo, called 'The evolution of military campaigns: general tendencies and applications'. ${ }^{61}$ Published several months later by the Min'yūsha company, the lecture offers multiple ways of understanding Inagaki's new audience and, consequently, the extent to which his thinking had developed in the five years after his departure from Cambridge. Indeed, this was a key period in Japan's relations with the Asia-Pacific world: on the one hand, the Meiji government had emerged victorious from the SinoJapanese War (1894-5); on the other, its ability to send additional labourers across the Pacific had been threatened, both by the rise of anti-Japanese campaigns in California (1892-4) and by white sugar planters in Hawai'i overthrowing the monarchy and establishing a republic in which Asians were now denied citizenship $(1893-4){ }^{62}$

Like much of Inagaki's work, the 1895 lecture seems unburdened by any desire for concision. After explaining that his aim is to trace the historical transformation of military campaigns up to the nineteenth century, he offers a detailed overview of world history according to four types of 'ambition' (he uses the phonetic katakana syllabary): personal, family, state, and finally 'national ambition' - a section which begins with Oliver Cromwell and the English Civil War. The Napoleonic wars served as the transition to the fifth stage, he continues, which was marked by a greater emphasis on 'humanity' as evidenced by Wilberforce's abolition of the slave trade, the expansion of global commerce, technological innovation, and so on, including what Inagaki terms 'world peace'. ${ }^{6}$ This meant that the use of military campaigns for the newly victorious Japan in 1895 became a question of the nation's 'responsibility' to maintain peace in East Asia, and, through peace, to cultivate world civilization. ${ }^{6} 4$ To fulfil this 'duty to the world', Inagaki called for a state policy of 'military expansion’ (gunbi kakuchō 軍備拡張), so as to attain for Japan a position of supremacy in East Asia, alongside a concomitant expansion of diplomatic power. Moreover, it would be crucial for Japan to advance in

${ }^{61}$ Inagaki Manjirō 稲垣満次郎, ‘Gaisei shinka no taisei oyobi sono ōyō' 外征進化の大勢及 其應用 ('The evolution of military campaigns: general tendencies and applications'), reprinted in Inagaki Manjirō, Gaikō to gaisei 外交と外征 (Diplomacy and military campaigns) (Tokyo, 1896; orig. edn 1895), pp. 83-170. Some scholars translate Tōhō Kyōkai as 'Eastern Association'.

62 Azuma, In search of our frontier, pp. 44-53.

63 Inagaki, 'Gaisei shinka', p. 141.

64 Ibid., pp. 154-5. Throughout the essay, Inagaki renders 'civilization' in katakana, alongside the word bunka 文化, today usually translated as 'culture'. For a detailed etymology of the latter, see Yanabu Akira 柳父章, Bunka: ichigo no jiten 文化 : 一語の辞典 (Culture: one-word dictionaries) (Tokyo, 1995). 
commerce and industry as part of its 'national interest' in Asia and in the Pacific. This would involve the opening and development of commercial ports, if necessary using a British-style 'gunboat diplomacy'. That is, Inagaki envisioned Japan opening shipping lines to support new trading bases both on the Asian continent and in the 'Southern Seas' and America, because, he claimed, 'With the completion of the Trans-Siberian railway and the [prospective] opening of the Nicaraguan canal, today's world is no longer in the Atlantic age but is surely moving into the Pacific age. ${ }^{\prime}{ }_{5}$

In the 'Pacific age', we have the fullest expression of a Seeley-esque temporal colligation. First, it was a phrase which tied together multiple strands of thought in early 1890 Japan, from overseas trade to gunboat diplomacy to stages of civilizational evolution. Second, it appeared in the 'application' section of Inagaki's lecture, as if nodding to Seeley's belief that history should pursue 'a practical object'. (Indeed, in a further nod to Seeley, the other key term in Inagaki's subtitle, taisei 大勢, was annotated to be phonetically pronounced as 'general tendency', perhaps recalling the first chapter of The expansion of England.) And, just as Seeley had framed historical expansion in terms of England's 'transformation', so Inagaki similarly placed transformations (hensen 変遷) in military expansionism at the heart of his historical analysis. ${ }^{66}$ In all of these ways, we can think of Inagaki as entering into a duet with Seeley's ideas.

But - to continue the musical metaphor-Inagaki's 1895 lecture should in fact be considered a modulation of The expansion of England into new keys rather than a straight transposition from one stave to another. For if this had been a simple case of what Korhonen calls 'transference', we might wonder why the student did not articulate the 'Pacific age' while writing his 1890 monograph in Cambridge - when, presumably, the 'guidance' of the professor was greatest. In fact, Inagaki did not arrive at this formulation until 1892, when he published a sequel to his own Tōhōsaku ippen 東方策一編 (Eastern policy, volume I). This 1891 book had been, in loose terms, an expanded translation of Japan and the Pacific, as we shall shortly see. The sequel, A draft with conclusions about Eastern policy (1892), built on Inagaki's previous groundwork. Its preface articulated for the first time the transition from 'Mediterranean age' to 'Atlantic age', and then to the world being on the verge of a 'Pacific age' (that is, the formulation to which Inagaki would return in 1895) ${ }^{67}$ But, whereas Eastern policy had focused on history, now - in September 1892 - was the time to discuss policies. In other words, Inagaki's first articulation of the 'Pacific age' was prompted by his concern to address the practical challenges faced by the early 1890 Japanese state, which for him ranged from commercial and industrial policy to military policy and international law. This suggests, in turn, that

\footnotetext{
65 Inagaki, 'Gaisei shinka', p. 162.

66 Ibid., p. 84 .

67 Inagaki Manjirō 稲垣満次郎, Tōhōsaku ketsu-ron sōan 東方策結論州案 (A draft with conclusions about Eastern policy) (Tokyo, 1892), p. 1.
} 
the intellectual environment of early 189 os Japan was as important to the development of Inagaki's thought as Seeley's ideas. To return to Joan Judge's formulation, this early 189 os environment therefore constituted Japan's 'existing conceptual universe' - a universe which already had its own distinctive ways of using the past.

Rather than asking how Inagaki 'introduced' Seeley to Japan, therefore, we might first question the extent to which stars from this universe could be seen in the Cambridge skies during the period $1885-90$. On the one hand, there seems little evidence that Inagaki read contemporary Japanese works during his student days. Based on Japan and the Pacific alone, his interlocutors included not only Seeley but also Oscar Browning, the King's College historian who had been present during Seeley's Swiss revelation, and whom Inagaki thanked in his preface; and Thomas Erskine Holland (1835-1926), whose work he acknowledged as having consulted 'specially for the history of treaties'. ${ }^{68}$ (The admiration was mutual: upon receiving a copy of Japan and the Pacific, Holland wrote, 'You have done good service in impressing upon us that beyond and behind our old "Eastern Question" there lies a Pacific Question, in the solution of which your wonderful country must play a leading part, and which it is now high time for us to study seriously. ${ }^{69}$ ) Elsewhere in his monograph, Inagaki cited historians of Russia and of the French empire, and biographies of Lord Palmerston and Richard Cobden, in addition to primary sources. All the cited authors were male and wrote in English.

On the other hand, the intellectual environment for Japanese students in late 188 os Cambridge seems to have been such that, even if Inagaki had been reading his Japanese peers, his citation of their work might not have been widely welcomed. As we have already seen, he was a founder member of the Japanese Club at Cambridge, whose stated object was to study both the 'qualities of the English Gentlemen' and 'how and where the high character of the English Gentleman is produced; and, having ascertained that certain qualities are possessed by the English Gentleman, to enquire into the best means of cultivating among ourselves the like qualities'. Part of this cultivation included, in February 1890 , a lecture by the Rev. Prof. B. G. Westcott, DD (of King's College) on 'The influence of Christianity upon the character of the English gentleman'- a lecture structured around the question of what 'does Christianity bring to the education of the English Gentleman which Confucius cannot bring'. $7^{\circ}$ If the considered position of a Cambridge don was that there were certain things even Confucius could not bring to the educational table, then we may have an insight into why Inagaki chose not to cite contemporary

68 Inagaki, Japan and the Pacific, p. 12. Oscar Browning was famously the object of Virginia Woolf's satire in her 1929 essay, A room of one's own.

69 T. E. Holland, professor of international law and fellow of All Souls College, Oxford, to Inagaki, 12 June 1890 , reprinted in Inagaki Tōhōsaku ( 5 th edn), front matter (unpaginated). $7^{\circ} \mathrm{JCC}$, minutes from the fourth meeting (Feb. 189o), pp. 2, 5 . 
Japanese-language scholarship in Japan and the Pacific-assuming that he had access to such scholarship.

That Inagaki may actually have had some ongoing connection to intellectual trends in his homeland is suggested elsewhere in the Japanese Club's minutes. It was mentioned in the December 1890 meeting that Inagaki had previously hosted a visit to Cambridge by 'Count Tokugawa', whose identity is otherwise unknown. Later, it was reported that Kikuchi Dairoku 菊池大麓 $\left(1855^{-}\right.$ 1917), himself a Cambridge graduate, often sent letters from Tokyo to Inagaki's close friend, the Rev. C. E. Searle: 'There is hardly one in which there is not some reference to Mr. Inagaki's proceedings at home and to the interest with which his proceedings are watched there. ${ }^{71}$ Visitors and letters, then, were two ways in which Inagaki might have kept abreast of new work being published in Japan. Other mediators may have been his fellow students in the Japanese Club. Soejima Michimasa 副島道正 (1871-1948), who arrived in 1888 to study at the Leys School but later read history at the university, was the third son of Soejima Taneomi 副島種臣 (1828-1905), the former foreign minister of Japan and member of the privy council; and Matsura Atsushi, whom Inagaki accompanied to Cambridge in 1885 , may well have provided another link to what was happening back in Hirado. $7^{2}$

Indeed, events in Hirado were emblematic of a shift in the ways that intellectuals in Japan were - in the same way as Inagaki in Cambridge-seeking to understand their country's place in the world in the late 188 os. In 1888 , for example, the aforementioned Suganuma Teifū returned to Hirado from his studies at the University of Tokyo bearing a copy of a novella, Tale of a dream of Hankai (1886), co-authored by Sugiura Shigetake 杉浦重剛 $\left(1855^{-1924)}\right.$ and Fukumoto Nichinan 福本日南 $(1857-1921)$. The novella imagined a fictional land, clearly resembling the Spanish Philippines, to which a group from Japan's outcaste community planned to emigrate. Enthused by this vision of southward expansion, Suganuma himself decided to prepare for such a mass emigration of his Hirado compatriots by going to the Philippines with Fukumoto.73 There, in 1889, he met an untimely death, but his vision of southward expansion chimed with the expansionist maritime visions of other journalists such as Taguchi Ukichi 田口卯吉 $\left(1855^{-1905}\right)$ or Shiga Shigetaka 志賀重昂 $\left(1863^{-1927}\right)$, whose report of his ten-month expedition to the south Pacific had been published in 1887.74 Fukumoto himself would maintain

$7^{11}$ JCC, minutes from the fifth meeting (Dec. 189o), pp. 12, 16 .

72 My thanks to Alison Lainchbury, librarian and archivist at the Leys School, Cambridge, for confirming that Soejima Michimasa was a pupil there, 1888-91: personal correspondence, 9 Nov. 2018.

73 On the 1886 novella Hankai yume monogatari 樊噲夢物語 (The tale of Hankai's dream), see Jun Uchida, 'From island nation to oceanic empire: a vision of Japanese expansion from the periphery', Journal of Japanese Studies, $4^{2}$ (2016), pp. 57-9o, at pp. 82-7.

${ }^{74}$ Shiga Shigetaka 志賀重昂, Nan'yō jiji 南洋時事. (Current events in the Southern Seas) (Tokyo, 1887); Taguchi Ukichi 田口卯吉, ‘Nan'yō Keiryaku-ron’ 南洋経略論 ('On strategies for the 
Suganuma's vision by posthumously publishing his friend's monograph on the commercial history of greater Japan. In his preface, Fukumoto drew on the rich pre-Tokugawa history of Hirado to imagine a world in which, in the absence of the maritime restrictions from the 163 os onwards, the promise of the early shogunate's 'red seal ships' system had been allowed to continue, leading to the raising of the Japanese flag in 'every port under the sun' and general national prosperity. ${ }^{75}$

As this one example shows, there was therefore a group of writers in the late 188 os - a 'literary network' including Shiga Shigetaka, Taguchi Ukichi, Sugiura Shigetake, Fukumoto Nichinan, and Suganuma Teifu-whose publications were inspired by concerns similar to those exercising Inagaki in Cambridge, namely how to place Japan and its past into global economic and political space. $7^{6}$ In other words, even before Inagaki 'introduced' Seeley's ideas to a Japanese audience, there was a pre-existing set of debates about maritime expansion, some of which looked back to Japan's own history of engagement in South-east Asia (as previously mentioned, this was what Akira Iriye termed the 'indigenous tradition' of Japanese expansionism). For many of these writers, moreover, Japan's ongoing colonization of Hokkaido and future expansion to the south were two sides of the same coin, driven as they were by the idea that overpopulation at home could be relieved by the settlement of Japanese overseas. 77

That Inagaki's 1891 book, Eastern policy, became a commercial success (its fifth edition appeared in 1894) suggests that he quickly learned how to speak to this audience. Partly this was a question of exposure. One Tokyo-based crowd with which he mixed was the Oriental Society, in whose journal, in November 1891, he published his article on international law and the Port Hamilton incident. The society's establishment had coincided with Inagaki's return to Japan six months earlier, and its founding members included Soejima Taneomi (father of Inagaki's Cambridge friend) and the aforementioned writer Fukumoto Nichinan. ${ }^{7}$ Inagaki himself was listed as a member

Southern Seas'), Tokyo nichi nichi shinbun, 22 March 1890 , reprinted in Teiken Taguchi Ukichi zensh $\bar{u}$ 鼎軒田口卯吉全集 (The complete works of Taguchi Ukichi [Teiken]), IV (Tokyo, 1990), pp. $371-3$. See also Schencking, 'Imperial Japanese navy'.

75 'Udai kakko' 宇内各港 ('Every port under the sun'); Fukumoto Nichinan 福本日南, 'Introduction', in Suganuma Teifū 菅沼貞風, Dai-Nihon shōgyōshi 大日本商業史 (A commercial history of greater Japan) (Tokyo, 1892), pp. 4-5. On the red seal ships (shuinsen 朱印船), see Birgit Tremml-Werner's contribution to this special issue.

$7^{6}$ Fukumoto Nichinan, Shiga Shigetaka, and Sugiura Shigetake 杉浦重剛 were also founder members of the Seikyōsha (Society for Political Education) in 1888. For the definition of literary networks as connecting 'Muslims across boundaries of space and culture, and [helping] introduce and sustain a complex web of prior texts and new interpretations that were crucial to the establishment of both local and global Islamic identities', see Ricci, Islam translated, pp. $1-2$.

77 Lu, 'Colonizing Hokkaido'.

$7^{8} T \bar{o} h \bar{o} k y \bar{o} k a i$ hōkoku, I, pp. 149-5o. Of the previously listed group of expansionist writers, Shiga Shigetaka was also a member (ibid., p. 287). In addition, there was much overlap 
for the first time in October 1891 , and by 1895 he was the society's secretarygeneral. As the journal's first issues demonstrate, the members' eclectic interests were a perfect fit with those of Inagaki: there were articles on Australia, on overseas migration, on the Ogasawara, Kuril, and Yaeyama islands, and on the comparative strength of the Japanese navy, all alongside translations of the French colonial advocate Paul Leroy-Beaulieu (1843-1916), and much more.79 That Inagaki chose to give his expanded translation of Japan and the Pacific a Japanese title - Tōhōsaku (東方策, Eastern policy) - which spoke directly to the society's interest both in 'the Orient' and in government policy may be considered an astute piece of marketing.

A second crowd with which Inagaki ingratiated himself was that associated with the Min'yūsha publishing house, led by his almost exact contemporary Tokutomi Sohō (1863-1957). Tokutomi had risen to public prominence during Inagaki's absence with the publication of his bestselling book, Shôrai no Nihon 将来之日本 (The future Japan), in 1886. As Christopher Hill has noted, this was an extended conversation with Herbert Spencer's Political institutions (1882), focusing particularly on the question of whether Japan could be restored to the 'general [global] tendencies' of social and societal development, notwithstanding its divergence from these tendencies during the Tokugawa period. ${ }^{80}$ This is not the place for an extended analysis of the similarities between Tokutomi's 1886 book and Inagaki's Japan and the Pacific, but the extent to which the two authors addressed the same questions is striking: the interest in general historical 'tendencies' (taisei); the focus on what Lord Knutsford termed 'the history of the future'; and thus the sense that both Tokutomi and Inagaki placed 'the European past and the Japanese future into an allegorical relationship in which it [was] possible to read one through the other' ${ }^{81}$ Again, we might question whether Inagaki's early interest in 'the coming century' and in historical tendencies was exclusively the result of his having imbibed Seeley's call for history to 'modify [the reader's] view of the present and his forecast of the future'.${ }^{82}$ If Tokutomi's star was another that Inagaki could see from Cambridge, then this would reinforce my suspicion that Japan and the Pacific, and its subsequent translations into Japanese, were partly informed by Inagaki's engagement with contemporary Japanese intellectual trends even during his years of overseas study.

If Inagaki had indeed read Tokutomi while studying in Cambridge, then perhaps it is not surprising that he initiated contact between the two in July

\footnotetext{
between the Oriental Society and the Shokumin Kyōkai 殖民協會 (Colonization Society), of which Inagaki became a founder member in April 1893.

79 On Leroy-Beaulieu, see Hill, National history and the world of nations, pp. 119-52.

8 Ibid., pp. $171-8$.

${ }^{81}$ Ibid., p. 177. We might borrow Hill's apt phrase 'future anteriority' (p. 159) to analyse Knutsford's characterization of Inagaki's work.

${ }^{82}$ Seeley, Expansion of England, p. 7.
} 
1891 , shortly after his return to Japan. ${ }^{83}$ In his first letter, he referred to a submission he had made to Tokutomi's newspaper, The Nation's Friend, which Tokutomi had founded with the proceeds earned by The future Japan. Inagaki's essay, 'The Japanese nation and international law', was subsequently published on 23 July 1891,84 marking the beginning of a relationship with Tokutomi and with his Min'yūsha publishing house that lasted at least until the publication of Inagaki's lecture in 1895, and which therefore spanned a crucial period in the development of Tokutomi's thought. For, as the story usually goes, Tokutomi's worldview underwent a transformation in the early 18 gos, from liberal 'friend of the people' (民友, min'y $\bar{u}$ ) to-in the words of his numerous critics - oligarchy-supporting 'friend of the government' ${ }^{85}$ Accordingly, the outbreak of the Sino-Japanese War in July 1894 was one factor in this 'conversion'. At the height of the war, in December 1894, Tokutomi published On the expansion of greater Japan, a book which predicted Japan's victory and which called for a much more militant form of Japanese overseas imperialism than that which he had previously espoused.

As Hill and others have argued, however, to overemphasize this 'conversion' is to ignore the extent to which Tokutomi had been interested in the state as a key historical player in The future Japan. ${ }^{86}$ Moreover, Tokutomi had signalled his interest in expansion in a piece he wrote for The Nation's Friend in June 189o, entitled 'A new homeland for the Japanese race'. What was significant about Tokutomi's article was its call for expansion in all but name. He lauded the Chinese race for being 'an expansive people (kōdai naru jinmin 広大なる人 民) living in an expansive empire (kōdai naru teikoku 広大なる帝国)'. He lamented that, even in Hokkaido, colonization was proceeding slowly, while elsewhere, the Japanese overseas population comprised only ten thousand labourers in Hawai' $i$, two to three thousand students in San Francisco, and prostitutes in Hong Kong and Singapore. (Sanuki Jūkichi, with whom I began this article, arrived in Australia from Hawai'i two weeks after Tokutomi's article was published.) In calling for policies to promote overseas migration (gaikoku $i j \bar{u}$ 外國移住), Tokutomi talked of the 'spread' of the Japanese race (man'en 蔓延), the need to make Japanese 'venture overseas' (kaigai ni yūhi seshimuru 海外に雄飛せしむる), and the imperative to 'open a new empire’ (shin-

83 The letter is reprinted in Shibasaki Rikiei 柴崎力栄, ‘Tokutomi Sohō ate Inagaki Manjirō shokan' 徳富蘇峰宛稲垣満次郎書翰 ('Inagaki Manjirō's letters to Tokutomi Sohō), Memoirs of the Osaka Institute of Technology, $5^{8}$ (2013), pp. 57-9, at p. $5^{8}$.

84 Inagaki Manjirō 稲垣満次郎, 'Bankoku kōhōjō no Nihonkoku' 萬國公法上の日本國 ('The Japanese nation and international law'), Kokumin no tomo, no. 125 (23 July 1891), reprinted in Meiji bunken 明治文献, Kokumin no tomo 国民之友 (The Nation's Friend) (Tokyo, 1966), IX, pp. 40-1.

${ }_{5}$ In English, see John D. Pierson, Tokutomi Sohō, I863-1957: a journalist for modern Japan (Princeton, NJ, 1980), pp. 199-247; Yushi Ito, Yamaji Aizan and his time: nationalism and debating Japanese history (Folkestone, 2007), pp. 123-5.

86 Hill, National history and the world of nations, pp. $17^{1-2 .}$ 
teikoku wo hiraku 新帝国を開く). Nowhere, however, did he use the term in the title of his 1894 book, 'expansion' $(b \bar{o} c h \bar{o}) .{ }^{87}$

This is significant because there seems to have been a subtle shift in how the idea of 'expansion' was expressed in the Japanese language in the period 189o-4. When, in his 1891 Eastern policy, Inagaki acknowledged Seeley's Expansion of England, he translated 'expansion' as kakuchō 拡張. ${ }^{88}$ This aligned with a tendency for writers to use kakuchō when discussing commercial expansion and Japanese emigration. For example, the eminent Fukuzawa Yukichi had argued, a few months before Inagaki's return to Japan, that 'The reason that English commerce prospers is due to there being so many Englishmen all over the world. In Japan, too, in order to expand (kakucho 拡張) trade and commerce with foreign countries, we first need to have our people settle far and wide in foreign lands ....89 And again, in January 1893, Fukuzawa examined the relationship between the 'expansion' of overseas shipping lines and Japanese trade and commerce. $9^{\circ}$ In this use of kakuchō, Fukuzawa was by no means exceptional: through the 1880 s, the term was used both in a material context (the expansion of the railways, telegraph lines, commerce) and, more abstractly, in terms of rights, duties, and laws. $9^{1}$

When Tokutomi came to write On the expansion of greater Japan, however, he rendered 'expansion' with the characters bōchō 膨張, not kakuchō. In the book's opening chapter, which was originally published as a stand-alone essay in June 1894, Tokutomi turned once again to history, and to the idea that Japan had diverged from its true historical identity during the Tokugawa period. If the history of the last few hundred years had been a history of contraction ( $s h \bar{u} s h u k u$ 収縮), he argued, then the history of coming centuries must be one of expansion ( $b \bar{o} c h \bar{o}$ no rekishi 膨張の歴史). In this scheme, the stories of Japan's mythical age referred to seas, islands, ships, vessels, whales, and sharks - all related to the maritime world (remember Inagaki's characterization of the Japanese as 'born sailors'). By contrast, the stories of China's mythical age looked back to the territorial - to celestial pillars, the land, carts, horses, snakes,

87 Tokutomi Sohō 徳富蘇峰, 'Nihon jinshu no shin-kokyō' 日本人種の新故郷 ('A new homeland for the Japanese race'), Kokumin no tomo, no. 85 (13 June 189o), reprinted in Meiji bunken, Kokumin no tomo, vi, pp. 283-5.

${ }^{88}$ Inagaki, Tōhossaku ( $5^{\text {th }}$ edn), p. 13. His full translation of The expansion of England had been Eikoku kakuchō-ron 英國拡張論.

89 Fukuzawa Yukichi 福沢諭吉, 'Tsūshō rikkoku' 通商立國 ('A nation of trade and commerce'), Jiji Shinpō, 19 March 1891, reprinted in Keiō Gijuku, ed., 慶應義塾編, Fukuzawa Yukichi zensh $\bar{u}$ 福沢諭吉全集 (The complete works of Fukuzawa Yukichi), XIII (Tokyo, 1960), p. 30.

$9^{\circ}$ Fukuzawa Yukichi 福沢諭吉, 'Imin to kōkai’ 移民と航海 ('Emigration and shipping'), Jiji Shinpō, 25 Jan. 1893, reprinted in Keiō Gijuku, Fukuzawa Yukichi zenshū, xIII, p. 371 . On Fukuzawa's call for Japanese to emigrate overseas, see Bill Mihalopoulos, 'An exercise in good government: Fukuzawa Yukichi on emigration and nation-building', Journal of Northeast Asian History, 9 (2012), pp. 5-29.

$9^{1}$ Dictionary entry for kakuchō 拡張 in Nihon kokugo dai-jiten 日本国語大辞典; text-specific search of the Kikuzō database for the Asahi shinbun newspaper in the 188 os (by subscription). 
or cattle. The Tokugawa shogunate had closed Japan to the world, but now even a farmer could cross the seas to work in Hawai' $i$. There were now Japanese pearl divers working directly below the Southern Star (i.e. in Australia), salmon and trout fishermen in the tributaries of the Amur river, sugar cultivators on volcanic islands (i.e. Hawai'i), and farmers in North America; there were Japanese all over the Korean peninsula, and elsewhere in Vladivostok, Singapore, Hong Kong, Vancouver, and Queensland. If four and a half centuries were to elapse, and the Pacific waves were to continue to swell, the light of the Southern Star continue to shine, and the warm stream of the Kuroshio current continue to flow, there would be no place without Japanese. 'Looking to the future,' Tokutomi wrote, drawing again on tropes of time

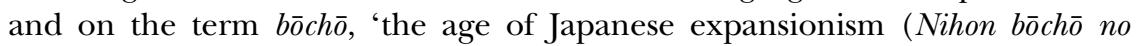
jidai, 日本膨張の時代) is an unquestionable fact.' $9^{2}$

In positing a future Japanese age (jidai) in world history, Tokutomi articulated a concern that was close to Inagaki's heart. Inagaki, indeed, had sent Tokutomi a copy of his A draft with conclusions about Eastern policy, the book in which he first articulated the 'Pacific age', in September 1892.93 But we also cannot help but notice that Tokutomi's trope of state-centred national expansion (encompassing both commerce and emigration and also race, colonization, and war) was similar to the colligation that Seeley had proposed in The expansion of England. That Seeley was being read in the Min'yūsha publishing house circles by the mid-189os is well known. Yamaji Aizan 山路愛山 $\left(1865^{-}\right.$ 1917) later recalled that 'the youth of Japan learned from the late Professor Seeley's The expansion of England about the destiny of races and the potential for imperial development'.94 Yamaji's own encounter with Seeley has been dated to 1897 , while the historian Sawada Jirō suggests that Tokutomi probably did not read Seeley until August $1893 .{ }^{95}$ But such research overlooks the fact

$9^{2}$ Tokutomi Sohō 徳富䔡峰, Dai-Nihon bōchō-ron 大日本膨張論 (On the expansion of greater Japan) (Tokyo, 1894), pp. 1-6; citation from p. 6. Tokutomi was by no means alone in this kind of imagination. For an example of expansionist ideologues from the Seikyōsha (see n. 76 above) positing the Japanese as an expansionist people using the term bōcho in 1896 , see Azuma, In search of our frontier, p. 281, n. 32. See also Amin Ghadimi, 'The federalist papers of Ueki Emori: liberalism and empire in the Japanese enlightenment', Global Intellectual History, 2 (2017), pp. 196-229, at p. 216 , for an articulation of Japanese expansion in the early 18 gos by Ueki Emori 植木枝盛 $(1857-92)$.

93 Shibasaki, 'Tokutomi Sohō ate Inagaki Manjirō shokan', p. 57.

94 Oka Toshirō 岡利郎 et al., eds., Min'yūsha shisō bungaku sōsho: Yamaji Aizanshū 民友社思 想文学叢書:山路愛山集 (Lectures on the intellectual world of the Min'yūsha group: the writings of Yamaji Aizan), II (Tokyo, 1985), p. 340. See also Yosuke Nirei, 'Globalism and liberal expansionism in Meiji protestant discourse', Social Science Japan Journal, 15 (2012), pp. $75^{-92}$, at p. 85 (where the sentence is only partially translated).

95 Ito, Yamaji Aizan and his time, p. 126; Sawada Jirō 澤田次郎, 'Tokutomi Sohō no Dai-Nihon bōchō-ron to Amerika: Meiji nijū nendai wo chūshin ni’ 徳富蘇峰の大日本膨張論とアメリカ : 明治20年代を中心に ('Tokutomi Sohō's On the expansion of greater Japan and America: with a focus on the Meiji 2os [1887-1896]'), Doshisha American Studies, 41 (2005), pp. 21-53, at p. 35 , n. $5^{\text {o. }}$ 
that Japan's pre-eminent expert on Professor Seeley-his own student, Inagaki-was active in Min'yūsha circles from July 1891 onwards, certainly with his own copy of The expansion of England in hand. Through Inagaki's mediation, Seeley was perhaps present in Tokutomi's thinking in exactly the period when Tokutomi began to emphasize a state-centred view of imperial expansion. $9^{6}$

As for Inagaki, it is worth noting that he did not use the word $b \bar{o} c h \bar{o}$ to articulate his notion of Japanese expansionism in his 1895 lecture. Instead, like Fukuzawa, he used the term kakucho when he discussed world commerce, as he did when he also called for a policy of military expansion. Meanwhile, he used a somewhat unusual, technical term for 'military campaign' (gaisei 外征), thus arguably distancing himself from the imperial rhetoric of Tokutomi. And yet, in 1899, when Inagaki came to be involved in a part-translation of The expansion of England, the key noun was now rendered bōcho 膨張, thus using the state-centred term for 'expansion' most associated with Tokutomi's 1894 book.97 In other words, if Seeley's work was present in Tokutomi's thinking, then Tokutomi's work was equally present in Inagaki's later translation of Seeley, giving this and subsequent Japanese renderings of The expansion of England a closer alignment to the militant expansionist moment of the SinoJapanese War than Inagaki's first translation of the title in 1891 .

Here was expansionist history co-produced in the discursive spaces between Europe and East Asia-between a particular vision of eighteenth-century Britain and one of twentieth-century Japan, between the Atlantic and the Pacific worlds, and not least between teacher and erstwhile student.

\section{V}

In May 1893 , Seeley himself gave a lecture to the Japanese Club at Cambridge. The speech, which survives only in the form of a Japanese summary, outlined how the 'intrepid race' of his audience had renounced their own civilization and adopted (saiyo 採用) that of the West. At the request of the club's honorary vice-president, Seeley's task had been to offer some points of reference to the assembled students. But, he said, 'Concerning Japan's adventurous experiment, I am not sure I can give any points of reference, because there is really no precedent [for such an experiment] in the people of England, bound as they have been by two thousand years of traditions.' $9^{8}$

${ }^{96}$ On the significance of the state in Seeley's thought, see Duncan Bell, 'Unity and difference: John Robert Seeley and the political theology of international relations', Review of International Studies, 31 (2005), pp. 559-79, at pp. 566-8.

${ }^{97} \mathrm{~J}$. R. Seeley シーレー氏原著, Eikoku bōchōshi-ron 英國膨張史論 (A history of the expansion of England), trans. Sekiguchi Ichirō 関口一郎 and Toki Kōtarō 土岐孝太郎 (Tokyo, 1899). The preface to this translation, by Inagaki, does not survive.

$9^{8}$ J. R. Seeley ジョン・ロバート・シーレー, 'Nihon gakusei ni taisuru kōen gaiyō' 日本學 生に對する講演概要 ('Summary of a lecture given to Japanese students'), in J. R. Seeley, Eikoku 
Seeley need not have been so coy. As I have argued in this article, his own particular rendering of English history, first published a decade before his Japanese Club speech, offered significant reference points to a group of young Japanese writers in the early 189 os. First and foremost among those who engaged with Seeley's work was Inagaki Manjirō. But there were others too, among them Tokutomi Sohō and latterly Yamaji Aizan, who noted in 1903 that 'Professor Seeley's depiction of the development of the Anglo-Saxon race is immediately of value in teaching about the future (zento 前途) of the Japanese race.'99 By 1918, Soejima Michimasa could be added to their number: a founder member of the Japanese Club while still a pupil at the Leys School, Soejima subsequently studied history at Cambridge and, like Inagaki before him, started publishing essays in the journal of the Oriental Society after his return to Japan. ${ }^{100}$ Soejima was involved in the first full translation of The expansion of England into Japanese in 1918: he wrote the preface, contributed the profile of Seeley in the book's appendix, and provided the notes for the summary of Seeley's lecture to the Japanese Club, which he had attended in 1893 . Though it was the translator, Katō Seijirō, who noted that 'the current situation of our Japanese empire, in its internal politics and international relations, in its colonial and maritime enterprises, and in several other respects, has a great deal in common with the situation during the British empire's expansion in the past', these were sentiments that Soejima would also surely have shared. Katō continued by suggesting that the reader in 1918 might even have the feeling that Seeley's book was analysing contemporary Japan - here, no doubt, thinking of the geopolitical opportunities for his country that would accompany Britain's anticipated victory in the First World War. This desire to read Britain's past into Japan's future may also explain why the translation was reissued in 1931, another pregnant moment in Japanese expansionism. Fifty years after its conception in the Swiss Alps, Seeley's Expansion of England continued to be a point of reference for imperial Japan.

All of this suggests three possible conclusions. First, a global intellectual history of actors such as Seeley needs to be reconstructed well beyond the Anglo-American spatial framework in which his work is usually discussed. ${ }^{101}$ My particular example has focused on Japan, but perhaps future research will uncover similar stories of intellectual engagement with Seeley's ideas in, say, China or South-east Asia. The time frame for such engagement may also

bōchōshi-ron: The expansion of England: tow [sic] courses of lectures 英國膨張史論 (The expansion of England: two courses of lectures), trans. Katō Seijirō 加藤政司郎 (Tokyo, 1918), pp. 529-35, at p. 533 .

99 Oka et al., eds., Yamaji Aizanshū, II, p. 340.

${ }^{100}$ See two essays by Soejima Michimasa 副島道正 in Tōhō kyōkai kaihō 東邦協會會報, 86 (April 1902) and 88 (June 1902).

${ }^{101}$ For one example of such an Anglocentric frame of analysis, see Daniel Deudney, 'Greater Britain or greater synthesis: Seeley, Mackinder, and Wells on Britain in the global industrial era', Review of International Studies, 27 (2001), pp. 187-208. 
force us to read beyond the immediate late nineteenth-century context of this article. What, for example, was the significance of the prominent war sceptic Kiyosawa Kiyoshi noting, in his diary entry for 17 November 1943, that, having read Seeley and understood how 'the expansion of England took place because it was not built upon war', he now wanted an answer to the counterfactual question of 'how it would have been if Japan had not engaged in war at all with China or Russia and, embracing the balance of powers, had set out on an English maritime political policy'. ${ }^{102}$ In parsing what he took to be Seeley's promotion of pacific imperial expansion, Kiyosawa took home a very different message from that first mediated by Inagaki and then developed by Tokutomi, as if to suggest that Japanese expansionist discourse in the $1890 \mathrm{~s}$ had in fact been founded on an incorrect reading of Seeley's interpretation of English history.

Second, such a reconstruction equally challenges historians to move beyond a theoretical framework of 'influence' or 'transference'. Yamaji Aizan may have concluded his aforementioned 1903 essay-emphasizing every word-by declaring that 'The Japanese people need their own Mill and their own Professor Seeley, written in their own national language.' But as I have shown, Inagaki's early 1890 s formulation of the 'Pacific age' was already a sophisticated modulation of Seeley's ideas into a Japanese political and historical lexicon; and, by the mid-189os, the wider discourse of 'expansion' ( $b \bar{o} c h \bar{o})$ had become as much a co-production that drew both on Japan's pre-Tokugawa histories of engagement with South-east Asia and on eighteenth-century British history as it was simply a transference (or 'import') from a British to a Japanese context. Indeed, the fact that $b \bar{o} c h \bar{o}$ had an afterlife, migrating from mid-189os Japan to late Qing China (see Jonathan Chappell's contribution to this special issue), raises the question of whether 'national language' (kokugo 国語) is a useful way of framing the movement of ideas from Europe to and within East Asia. Perhaps, instead, we should think of communities of scholars, conversing across and between national borders, co-producing narratives and terminologies which may have spoken to particular needs in national history-writing but which were profoundly global in their composition. ${ }^{103}$

The third conclusion concerns the agents of these historical co-productions. The late 188 os are often seen as a transformative moment in the way that Japanese scholars conceptualized the past, as symbolized by the arrival of Ludwig Rieß (1861-1928) to establish the first department of history at Tokyo Imperial University in 1887 . Recent research has emphasized that 'modern' historical study in Japan also emerged out of an interplay between German and 'indigenous' Japanese practices, particularly when it came to the conceptualization of the archive. But such research still focuses in the main

\footnotetext{
${ }^{102}$ Eugene Soviak, ed. and trans., and Tamie Kamiyama, trans., A diary of darkness: the wartime diary of Kiyosawa Kiyoshi (Princeton, NJ, 1999), p. 108.

103 See Mervart, 'Republic of letters', pp. $34^{-} 5$.
} 
on professional historians as the key players in 'making history matter'. ${ }^{104} \mathrm{By}$ contrast, Inagaki's career between the mid-1 88 os and the late 1890 os forces us to consider the importance of writers who used the past to write history as non-professionals - even if, as in Inagaki's case or later Soejima's, they had a high level of historical training from one of the world's best universities. That Inagaki fell between several professional stools - historian, journalist, 'political economist', and later diplomat in Thailand and then Spain, before his premature death in 1908 - may explain why his work is less well known both inside and outside Japan. But, for a short period in the 189 os, he also made history matter.

Finally, there are those other agents of Japanese expansionism: men and women like Sanuki Jūkichi. By the mid-193os, this first generation of pacific transpacific migrants were being lauded by metropolitan writers and bureaucrats as 'pioneers' of later Japanese colonial expansionism. This, too, was a specific writing of the past. ${ }^{105}$ But whether Sanuki would have seen his own life in such a way is unknown: in a global intellectual history, these actors remain no easier to cite than to site.

\footnotetext{
${ }^{104}$ Margaret Mehl, 'The European model and the archive in Japan: inspiration or legitimation?', History of the Human Sciences, 26 (2013), pp. 107-27; Lisa Yoshikawa, Making history matter: Kuroita Katsumi and the construction of imperial Japan (Cambridge, MA, 2017). Rieß in fact knew of Inagaki and cited Japan and the Pacific for its prediction (p. 69) that England would one day occupy Taiwan because of the island's strategic significance: Ludwig Rieß, 'Geschichte der Insel Formosa', Mitteilungen der deutschen Gesellschaft für Natur- und Völkerkunde Ostasiens, 6 (1897), pp. 405-47, at p. 446. My thanks to Birgit Tremml-Werner for this reference.

${ }^{105}$ Eiichiro Azuma, "Pioneers of overseas Japanese development": Japanese American history and the making of expansionist orthodoxy in imperial Japan', Journal of Asian Studies, 67 (2008), pp. 1187-1226; Martin Dusinberre et al., 'The changing face of labour between Hawai' i, Japan and colonial Taiwan', Historische Anthropologie, 27 (2019), pp. 336-6o.
} 